\title{
FECUNDITY VARIATION AND ABUNDANCE OF FEMALE BLUE CRABS CALLINECTES SAPIDUS RATHBUN, 1896 (DECAPODA, BRACHYURA, PORTUNIDAE) IN THE PATOS LAGOON ESTUARY, RS, BRAZIL
}

\author{
MARCOS ALANIZ RODRIGUES, MARINA FEDERHEN HEBERLE, FERNANDO D'INCAO \\ Universidade Federal do Rio Grande - Instituto de Oceanografia - Laboratório de Crustáceos Decápodos - Caixa Postal 474, CEP $96201-900$ \\ - Rio Grande - RS - Brasil. alanizmarcos@gmail.com
}

\section{RESUMO}

Variação da fecundidade e abundância de fêmeas de Callinectes sapidus Rathbun 1896

(Decapoda, Brachyura, Portunidae) no estuário da Lagoa dos Patos, RS, Brasil

Neste trabalho são estudadas a variação na fecundidade e a abundância de fêmeas do siri-azul Callinectes sapidus Rathbun, 1896 no estuário da Lagoa dos Patos, Rio Grande do Sul, Brasil. Foram realizadas coletas junto à barra da Lagoa dos Patos entre novembro de 2008 e outubro de 2009. Os ovos das fêmeas foram retirados, pesados, contados e relacionados com as medidas morfométricas. Também foi relacionada a abundância das fêmeas ovígeras coletadas na área de desova com parâmetros ambientais. A fecundidade variou de 152.799 a 2.573 .576 ovos. Foi encontrada uma correlação positiva entre a fecundidade e a largura de carapaça. Foram encontradas fêmeas ovígeras de novembro de 2008 a maio de 2009, e em outubro de 2009. A fecundidade da espécie para o estuário da Lagoa dos Patos parece ficar dentro dos limites encontrados em outros estuários de ocorrência, sugerindo que exista um padrão em seu potencial reprodutivo. A espécie apresenta um período de desova bem marcado durante o período que compreende o final da primavera e todo o verão. Faz-se necessária a proteção do estoque de fêmeas com potencial para desova no estuário da Lagoa dos Patos, visto que delas depende o recrutamento da espécie na temporada reprodutiva seguinte.

PALAVRAS CHAVE: Decapoda, Portunidae, Callinectes sapidus, fecundidade, abundância

\section{ABSTRACT}

Female fecundity and abundance of the blue crab Callinectes sapidus Rathbun, 1896 varied according to size in the Patos Lagoon estuary, Rio Grande do Sul, Brazil. Sampling was done near the mouth of the estuary from November 2008 to October 2009. Eggs were removed, weighed, counted and related to morphometric measures. We also compared abundance of ovigerous females collected in the spawning area with environmental parameters. The fecundity ranged from 152,799 to 2,573,576 eggs per female, and showed a positive correlation with carapace width. Ovigerous females were found from November 2008 to May 2009, and in October 2009. Fecundity of the species in the Patos Lagoon estuary falls within the limits found in other estuaries, suggesting a pattern in the reproductive potential of $C$. sapidus. The species has a spawning season well known to occur during the late spring and summer, and as such it is necessary to protect the entire stock of spawning females, as these individuals allow for recruitment of juveniles during the next breeding season.

KEYWORDS: Decapoda, Portunidae, Callinectes sapidus, fecundity, abundance

\section{INTRODUCTION}

Fecundity in crustaceans is generally defined as the number of eggs produced by a female, during a particular spawning season. Among the Brachyura, there is considerable variation in fecundity, often varying as a function of female body size (Hines, 1988). Fecundity is an important population parameter for species of commercial value as it allows for estimates of the reproductive potential of the species (Mantelatto \& Fransozo, 1997, Dumont \& D'Incao, 2004).

Fecundity is a key factor in the persistence of a fisheries stock and is used to evaluate the status of a population because it has direct effects on the recruitment of species in estuarine and marine environments (Begg \& Waldman, 1999) such as the blue crab, Callinectes sapidus. The fecundity of portunids in the Southeast Southern Brazil was studied for Callinectes danae (Branco \& Avilar, 1992, Pereira et al. 2009) for Achelous spinimanus Latreille, 1819 (Santos, 1994) for Callinectes ornatus (Mantelatto \& Fransozo, 1997) and for Callinectes sapidus, in Babitonga Bay,
Santa Catarina (Pereira et al. op cit.). The reproductive process of the blue crab is complex, involving a series of behavioral and physiological phases, which include courtship, mating and signaling (Jivoff et al. 2007). It begins in the upper zones of estuaries in late winter, where males and females meet to copulate following the puberty molt (Hartnoll, 1969). Fertilized females then make their way down-estuary to the most saline waters in order to develop and maintain their egg masses until hatching of larvae (Aguilar et al., 2005).

The blue crab is an important fisheries resource throughout the Atlantic, considered to be a key benthic predator (Kennedy \& Cronin, 2007). Melo (1999) established the geographic distribution limits of C. sapidus in Brazil to be between Bahia and Rio Grande do Sul states. This species occurs along beaches in shallow depths, as well as in bays, estuaries and ponds. Observed declines in blue crab abundance demonstrate the need for a thorough understanding of the species' life history in order to 
optimize the management of the resource for fishing (Mendonça et al. 2010). In this study we used data on fecundity and abundance of females in the spawning area of the Patos Lagoon estuary, RS, Brazil to evaluate the existence of a relationship between individual size and reproductive potential. The Patos Lagoon estuary is a key location on the abundance of blue crabs. It is subjected to the influence of Rio de la

\section{MATERIAL AND METHODS}

Samplings were conducted for 12 months, from November 2008 to October 2009. Samples were collected near the mouth of the Patos Lagoon, on the West shorebreak, with a beach seine (Benedet et al., 2010) pulled by two people for an average distance of 150 meters. The nearshore oceanic region adjacent to the Patos Lagoon is considered to be very important to the successful spawning of $C$. sapidus (Rodrigues \& D'Incao, 2008). From the 245 ovigerous females collected and frozen for posterior biometry, 38 females were selected for analysis.

In the laboratory, specimens were unfrozen and pleopods with the egg mass were removed. Eggs were carefully removed from the pleopods and preserved in $70 \%$ ethanol for subsequent counting.

Measurements were made of carapace width (CW) (from the first spines of the antherolateral margin of the carapace) in millimeters, abdomen width (AW) in millimeters, wet weight (W) in grams, number of eggs (NE) and weight of eggs (WE) in grams (Mantelatto \& Fransozo, 1997; Oliveira, 2005).

The 38 females that were analyzed were chosen by selecting crabs with embryos in developmental stages from late blastula to early gastrula, then separated into $5 \mathrm{~mm} \mathrm{CW}$ size classes, whose egg masses presented color from white-yellow to dark orange (Mantelatto \& Fransozo, 1997). To describe the reproductive potential, estimates were made of the relationship between the number of eggs (NE) and the carapace width (CW), between the number of eggs and the weight of the egg mass (WE), between the number of eggs and the wet weight $(W)$, between the number of eggs and the abdomen width (AW), between the egg weight and the carapace width, and between the carapace width and the egg weight (Relationships summarized in Table 3 ).
Plata Coastal Waters (CW - Piola, 2002) what brings fresh water that can reach as far as the state of São Paulo. Data on fecundity were compared with other studies on three species of the Callinectes genus that occur in the estuary, whose recruitment are also subjected to $\mathrm{CW}$. It was also tested if temporal variation in the abundance of females might show differences in the reproductive pattern.

The methodology for fecundity estimates used was adapted from Barutot (2007) and Diaz et al. (1983). The egg masses that had been previously removed from pleopods were dried at $60^{\circ}$ for 24 hours, to allow for dry weight to be taken. From each egg mass, three subsamples were randomly separated, weighed and counted under a stereoscope microscope in a Sedgewick-Rafter counting cell. From the 1000 squares of $10 \mathrm{~mm}^{2}$ area each, 300 squares were counted, in three replicas of 100 . The number of eggs for each of the three replicas were summed and extrapolated for the total number (1000 squares) to obtain the number of eggs of the subsample. This estimate was divided by the weight of the subsample to obtain the weight of one egg in each subsample. The number of eggs of the sample was obtained by the average of eggs from the three subsamples. The total number of eggs for each female was extrapolated from the dry weight of the whole egg mass.

Data that included linear measurements (CW, $\mathrm{AW}, \mathrm{NE}$ ) were analyzed using a linear regression, while data including volumetric variables (WE, W), were analyzed with an exponential regression.

For the relative abundance analysis the catch-perunit-effort (CPUE) was calculated as number of individuals per 2 samplings per month. Histograms were constructed with the distribution of ovigerous females in $5 \mathrm{~mm}$ size classes. These were adjusted to a normal distribution using the software PeakFit 4.0 (SPSS) to determine if distinct year classes were present in the sample. The age of the females of each size class was estimated using the growth curve derived for the Patos Lagoon estuary by Rodrigues \& D'Incao (2008).

Total abundance data were plotted against the average air temperature (obtained from INMET: 
www.inmet.gov.br), water temperature, and salinity both inside and outside the estuary close to the sampling point. This graphic allows for visual inspection of the relationship between environmental parameters and the abundance changes during the sampling period. Finally, a multiple linear regression was performed to determine which of the environmental factors had more influence on CPUE.

\section{RESULTS}

The ovigerous females ( $\mathrm{N}=245)$ used in the abundance analyses ranged from 66.47 to $152.63 \mathrm{~mm}$

(average of $112.11 \pm 14.32 \mathrm{~mm}$ ). The distribution of the carapace widths appeared to be normal (Figure 1).

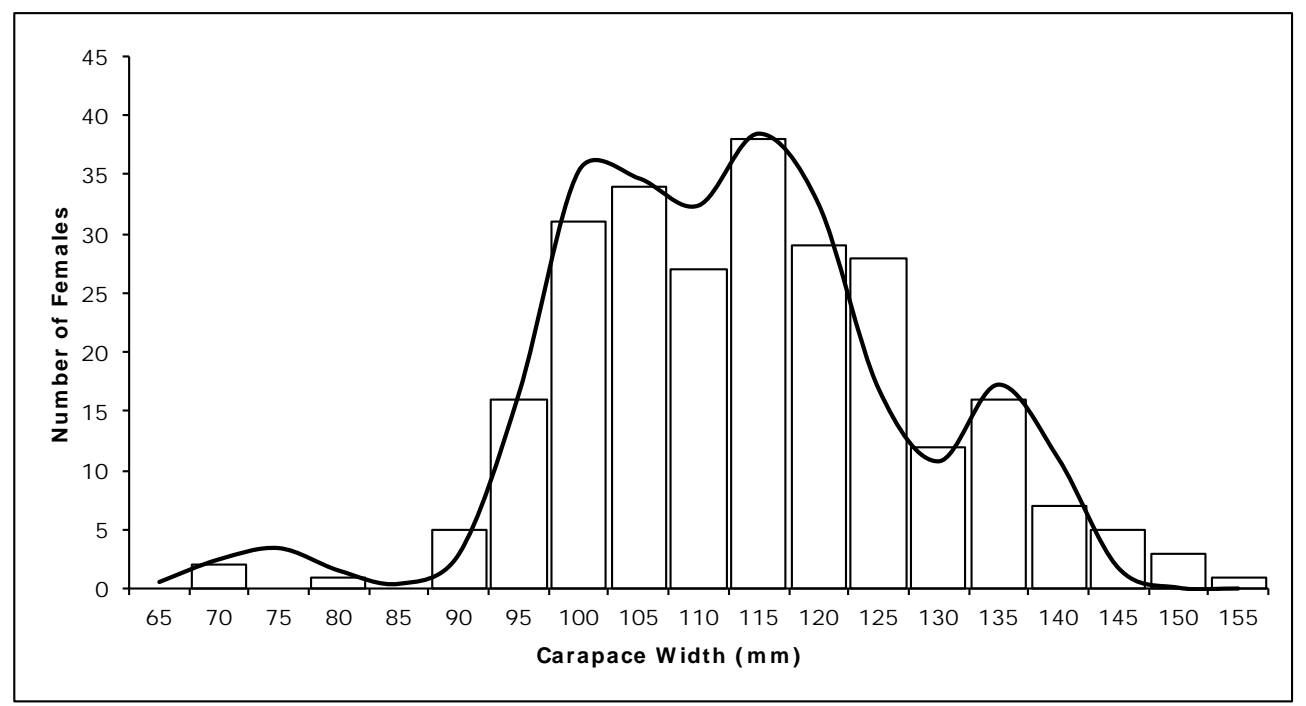

FIGURE 1 - Frequency distribution of the carapace width of 245 ovigerous Callinectes sapidus females collected near the mouth of the Patos Lagoon estuary. The solid line represents the smoothed frequency distribution, with four modes present.

Individual fecundity varied from 152.799 eggs (CW=79.26 $\mathrm{mm})$ to $2,573.576$ eggs $(\mathrm{CW}=114.9 \mathrm{~mm})$, while the mean count was $1,186.407 \pm 555.279$ SD eggs (Table 1). The fecundity frequency distribution also appeared approximately normal (Figure 2).

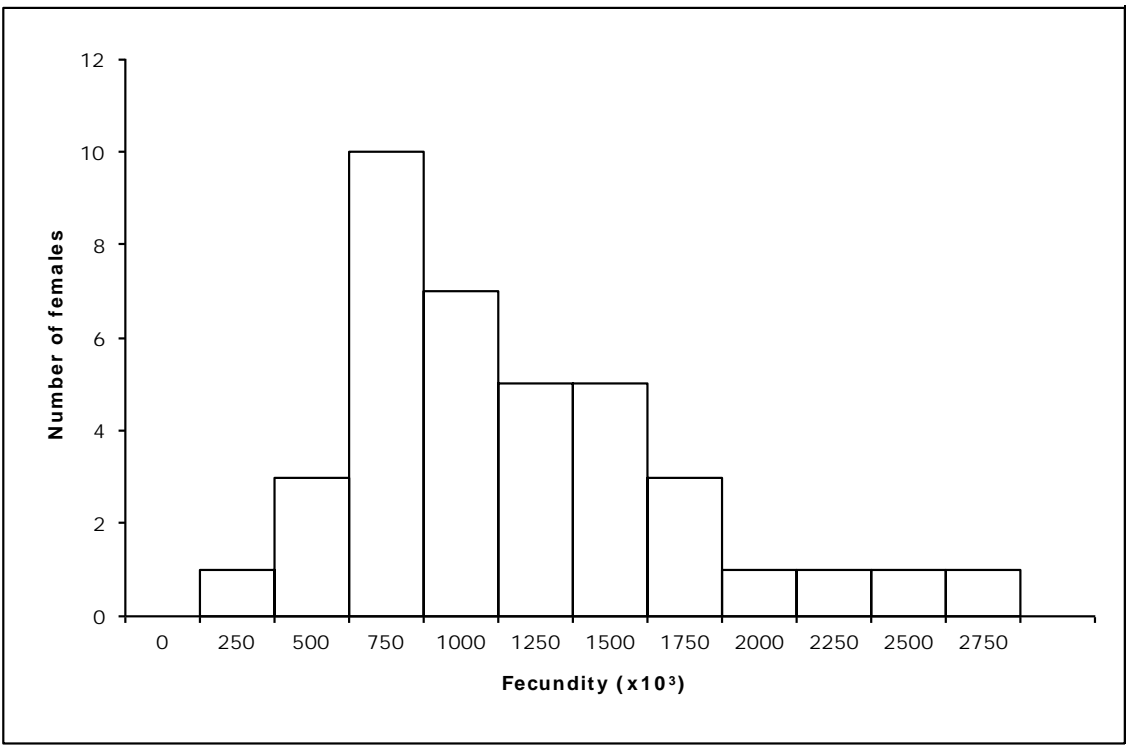

FIGURE 2 - Frequency distribution of the fecundity (number of eggs per individual) of 38 Callinectes sapidus females collected in the Patos Lagoon estuary spawning region. 
TABLE 1 - Comparison of the number of eggs (NE) and the dried egg mass weight (EW) on the size classes studied for $C$. sapidus.

\begin{tabular}{cccc}
\hline Class $(\mathrm{mm})$ & Number of & NE & EW \\
\hline $70.0-74.9$ & 4 & $550139 \pm 195530$ & $1.76 \pm 0.36$ \\
$75.0-79.9$ & 5 & $601444 \pm 296009$ & $2.48 \pm 0.58$ \\
$80.0-84.9$ & 6 & $805103 \pm 117221$ & $2.44 \pm 0.52$ \\
$85.0-89.9$ & 3 & $595486 \pm 1716$ & $2.38 \pm 0.87$ \\
$90.0-94.9$ & 3 & $957715 \pm 176895$ & $3.58 \pm 1.71$ \\
$95.0-99.9$ & 2 & $866943 \pm 510241$ & $3.84 \pm 1.35$ \\
$100.0-104.9$ & 2 & $1513106 \pm 91498$ & $8.41 \pm 3.63$ \\
$105.0-109.9$ & 4 & $1156340 \pm 216463$ & $8.37 \pm 2.08$ \\
$110.0-114.9$ & 4 & $1601217 \pm 662776$ & $9.84 \pm 3.06$ \\
$115.0-119.9$ & 2 & $1437378 \pm 174682$ & $12.15 \pm 0.007$ \\
$120.0-124.9$ & 2 & $2263436 \pm 30837$ & $12.55 \pm 2.15$ \\
$125.0-129.9$ & 1 & 1888582 & 12.22 \\
\hline
\end{tabular}

The frequency distribution of the ovigerous females contains four modes representing four distinct cohorts of females present in the spawning area, with carapace widths of $73.93 \mathrm{~mm}, 101.01 \mathrm{~mm}, 116.7 \mathrm{~mm}$ and 136.07 respectively (Figure 1). Ages calculated with the von Bertalanffy curve (Rodrigues \& D'Incao, 2008) for each of these cohorts are presented in Table 2.

TABLE 2 - Age of $C$. sapidus calculated for the average carapace width of each of the four cohorts of ovigerous females collected.

\begin{tabular}{cccccc}
\hline Total Width & L Infinity & $\mathrm{k}$ & t0 & Age (Days) & Age (years) \\
\hline 73.93 & 157.78 & 0.004 & -3.71 & 154.3 & 0.42 \\
101.01 & 157.78 & 0.004 & -3.71 & 251.83 & 0.69 \\
116.7 & 157.78 & 0.004 & -3.71 & 328.9 & 0.90 \\
136.07 & 157.78 & 0.004 & -3.71 & 492.14 & 1.34 \\
\hline
\end{tabular}

As shown in Figure 3, there is a positive correlation between the carapace width (CW) and the number of eggs $(\mathrm{NE})\left(r^{2}=0.61\right)$, which may indicate an increase in fecundity with an increase in size. The same pattern can be observed in the relationships between the other morphometric variables measured (Table 3).

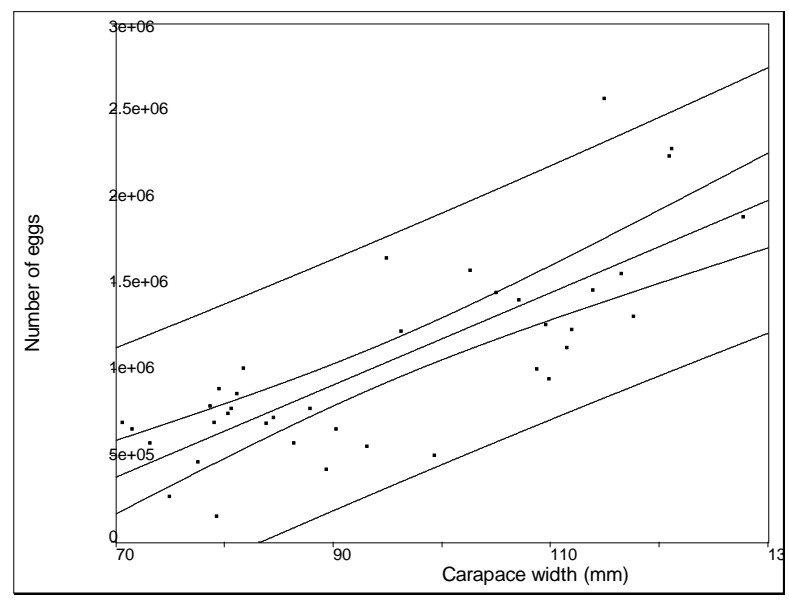

FIGURE 3 - Relation between carapace width (CW) and number of eggs (NE) of $C$. sapidus. Regression equation: $N E=26695 . C W-1 E+06\left(r^{2}=0.61\right)$. The central line is the mean, while the secondary lines are the $95 \%$ confidence interval (inner lines) and the prediction interval (outer lines), respectively. 
TABLE 3 - Regression analysis of $C$. sapidus fecundity. ( $r=$ correlation coefficient; $N E=$ number of eggs; $C W=$ carapace width; $\mathrm{AW}=$ Abdomen width; $\mathrm{W}=$ wet weight of ovigerous females; $\mathrm{EW}=$ dry weight of eggs). $\mathrm{N}=38$.

\begin{tabular}{llr}
\hline Relation & Linear & $r(\%)$ \\
& $\mathrm{Y}=\mathrm{a}+\mathrm{bX}$ & \\
\hline $\mathrm{NEXCW}$ & $\mathrm{NE}=1 \mathrm{E}+06+26695 . \mathrm{CW}$ & 0,61 \\
NE X AW & $\mathrm{NE}=-1 \mathrm{E}+06+57793 \mathrm{AW}$ & 0,55 \\
\hline Relation & Exponential & $\mathrm{r}(\%)$ \\
& $\mathrm{Y}=\mathrm{a} \cdot \mathrm{b}^{\times}$ & \\
\hline NE X W & $\mathrm{NE}=20512 \mathrm{~W}^{0,84}$ & 0,62 \\
NE X EW & $\mathrm{NE}=1.64 \mathrm{E}-06 \mathrm{EW}^{1.08}$ & 0.66 \\
EW X AW & $\mathrm{AW}=1.81 \mathrm{E}-05 \mathrm{EW}^{3.39}$ & 0.76 \\
EW X CW & $\mathrm{CW}=6.25 \mathrm{E}-08 \mathrm{EW}^{3.98}$ & 0.85 \\
EW XW & $\mathrm{W}=0.008 \mathrm{EW}$ & 0.85 \\
\hline
\end{tabular}

We sampled from November 2008 until May 2009 (Figure 4), but in the months of April, June, August and September of 2009, ovigerous females were not found. Abundance of females was significantly related to water temperature $(\mathrm{p}=0.0006)$, but was not related with any of the other environmental parameters measured.

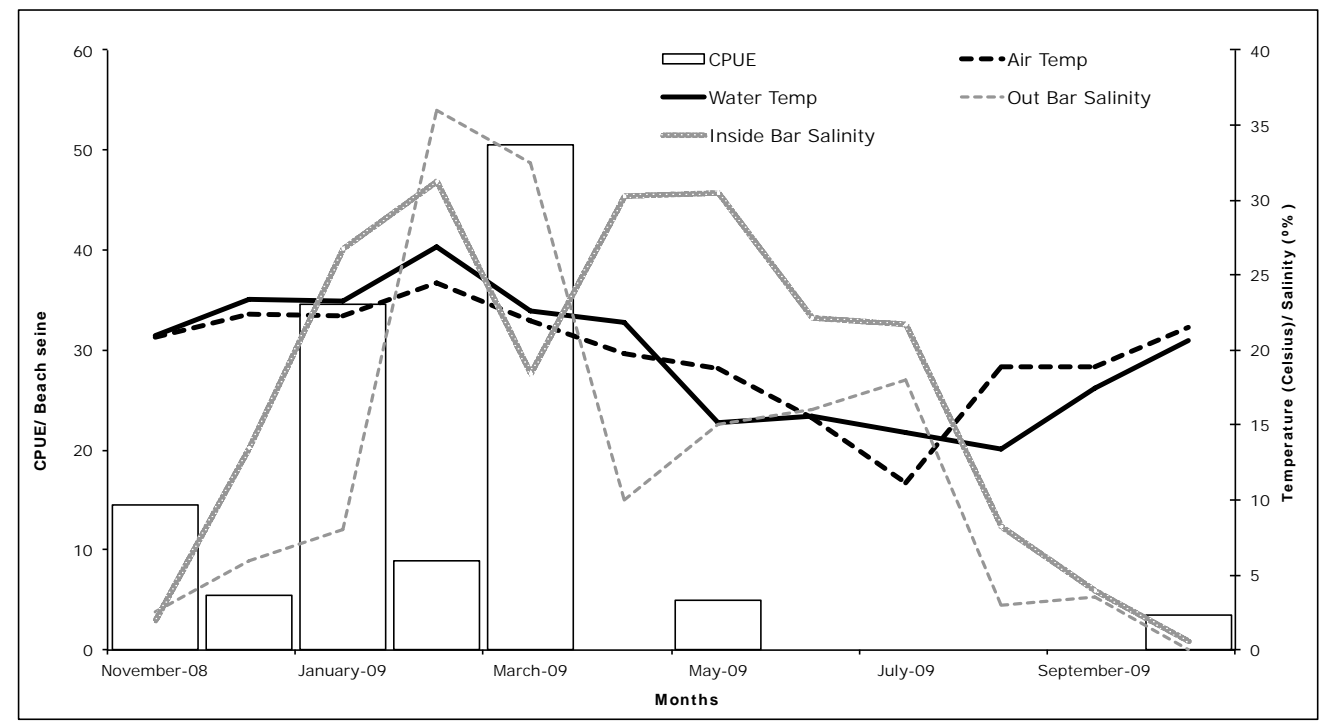

FIGURE 4 - Average air and water temperature as well as salinity inside and outside the mouth of the Patos Lagoon estuary, with CPUE of females collected monthly in the spawning area. The black lines represent temperatures (thatched=water temperature, dashed=air temperature), grey lines are salinity (thatched=inside lagoon, dashed=outside).

Table 4 summarizes fecundity data from our work, and on the literature for other species of the genus Callinectes that occur in the Patos Lagoon estuary. Data on fecundity of Callinectes affinis, Fausto-Filho, 1980, a portunid crab misidentificated for the estuary as Callinectes bocourti A. MilneEdwards, and recently validated by Robles et al. (2007) was not found, emphasizing the need for further work on this species. 
TABLE 4 - Comparison of fecundity between $C$. sapidus and other portunids also found in the Patos Lagoon estuary. Adapted from Mantelatto \& Fransozo (1997).

\begin{tabular}{|c|c|c|c|c|}
\hline Species & Study Area & Author & $\begin{array}{l}\text { CW min-max. } \\
(\mathrm{mm})\end{array}$ & Fecundity - min-max. (mean) \\
\hline $\begin{array}{l}\text { Callinectes } \\
\text { sapidus }\end{array}$ & USA & Churchill (1918) & - & $1,750,000-2,000,000$ \\
\hline $\begin{array}{l}\text { Callinectes } \\
\text { sapidus }\end{array}$ & USA & Truitt (1939) & - & $700,000-2,000,000$ \\
\hline $\begin{array}{l}\text { Callinectes } \\
\text { sapidus }\end{array}$ & USA (Virginia) & Prager et al. (1990) & $129.3-156.1$ & $1,230,000-4,500,000(3,200,000)$ \\
\hline $\begin{array}{l}\text { Callinectes } \\
\text { sapidus }\end{array}$ & Babitonga Bay (SC) Brazil & Pereira et al. (2009) & $100.0-150.0$ & $651,241-1,704,300(978,109)$ \\
\hline $\begin{array}{l}\text { Callinectes } \\
\text { sapidus }\end{array}$ & Patos Lagoon (RS) Brazil & Present study & $70.54-127.72$ & $152,799-2,573,575(1,046,803)$ \\
\hline Callinectes danae & Cananéia (SP) Brazil & Yamamoto (1977) & $30.0-44.0$ & $147,023-789,407(400,989)$ \\
\hline Callinectes danae & Vitória (ES) Brazil & Sá (1987) & $34.8-51.0$ & $229,000-1,064,000$ \\
\hline Callinectes danae & Rio de Janeiro (RJ) Brazil & Medeiros \& Oshiro (1990) & $72.4-106.8$ & $447,000-2,190,000(783,000)$ \\
\hline Callinectes danae & Florianópolis (SC) Brazil & Branco \& Avilar (1992) & $75.0-110.0$ & $111,549-1,292,190(598,885)$ \\
\hline Callinectes danae & Babitonga Bay (SC) Brazil & Pereira et al. (2009) & $70.0-110$ & $618,667-811,267$ \\
\hline Callinectes danae & Ubatuba (SP) Brazil & Costa (1995) & $48.0-83.0$ & $363,660-826,638(477,646)$ \\
\hline $\begin{array}{c}\text { Callinectes } \\
\text { ornatus }\end{array}$ & Ubatuba (SP) Brazil & Mantelatto \& Fransozo (1997) & $46.0-61.0$ & 56,817 - $379,815(171,570)$ \\
\hline
\end{tabular}

\section{DISCUSSION}

The fecundity of Callinectes sapidus in the Patos Lagoon estuary is similar to other inhabited estuaries (Table IV). Methods of obtaining fecundity varied through time (Diaz, 1983, Barutot et al., 2009), possibly explaining some of the differences in fecundity estimates obtained for $C$. sapidus in other studies. It is clear that among the species that occur in the Patos Lagoon estuary, $C$. sapidus produces the most eggs.

The portunids typically produce more eggs than other families of crabs, perhaps due to the high amount of eggs lost from unfertilization, but also because of diseases and parasites (such as the nemertean Carcinonemertes $s p$. and the barnacle Octolasmis muelleri) that decrease the total viability of the future breed (Voris \& Jeffries, 2001; Mantelatto et al. 2003).

Jacobs et al. (2003) determined that in the Gulf of Mexico there is a difference between the size of $C$. sapidus eggs from spring and late summer, but this is due to differences in water content, not to increased organic material. Diameter of eggs were not measured in this study because of viability reasons: the eggs were preserved in ethanol $70 \%$, losing most of their water content, and therefore were not considered accurate measurements of egg diameter.

There is great variation in fecundity among
Brachyura: the grapsoid crab Neohelice granulata (Dana, 1851) can carry an average of 28.000 eggs (Barutot et al, 2009) while some majids have highly variable fecundity, ranging from 4 to 180 million eggs per female (Schejter \& Spivak, 2005). A species that relies on a large number of eggs tends to use a reproductive strategy $(r)$ rather than parental care $(K)$. The fecundity for $C$. sapidus in the Patos Lagoon estuary is similar to other inhabited estuaries (Table 4), suggesting that there is a pattern in its reproductive potential even though there is a distinctly separate distribution based on geographical region of the Atlantic Ocean (Melo, 1999).

Data from ovigerous female abundance suggests that the species spawns from the end of spring through the beginning of autumn (from October to April). In the Patos Lagoon estuary this period is marked by an increase in the average temperature compared to the winter (National Meteorology Institute - INMET). Mantelatto \& Fransozo (1997), studying Callinectes ornatus on the shore of Ubatuba, São Paulo, describe two distinct spawning periods, which they attribute to the more consistently warm temperatures as a result of the temperate location of Ubatuba. The abundance of females in the spawning 
region of Patos Lagoon peaked at the end of summer, and the abundance of ovigerous females appears to be positively correlated with salinity (figure 4). However, in spite of high salinity from April to June, the abundance of ovigerous females declined during this period, suggesting that temperature is the main environmental factor responsible for the decrease of these individuals in catches in the estuary (Figure 4), what has been confirmed by the statistical analysis. The Patos Lagoon estuary is in a warm-temperate transition biogeographical zone, due to the influence of the Subtropical Convergence of the Southwest Atlantic (Seeliger et al, 1998). It is also subjected to the Río de la Plata freshwater discharges (Piola, et al. 2005) that in some extent limit the distribution of planktonic organisms, Callinectes sapidus larvae included. When conditions are favorable, most females increase weight rapidly, mature quickly and direct much of their biomass to reproduction, leading to an increase in the average fecundity of the population (Prager et al., 1990). If eggs from these females hatch during the optimal peak of salinity and temperature (e.g. March), larvae have their best chance of survival. High larval survival, along with factors such as larval retention and transport back into the estuary will allow this cohort to succeed. When females hatch their eggs at the end of the spawning season, larvae are subjected to an adverse environmental situation, and high mortality can be expected for this cohort.

The four size classes of females spawning in the estuary allow us to infer the existence of four distinct cohorts of spawning females. The first cohort consists of young females, less than six months old. The second and third cohorts represent females that are medium in size, while the fourth cohort represents the largest females. These largest individuals have higher reproductive potential and should be responsible for the greatest number of eggs released in the spawning area. The first cohort of young females likely copulated at a young age, and the second and third cohorts are probably the result of the main spawning peak during the previous year. The fourth and final cohort represents females that didn't mate during their first year of life.

Because larger females carry more eggs and produce more numerous offspring, it is hypothesized that the size class of females over $130 \mathrm{~mm}$ is critical to the success of recruitment the following year, because the number of eggs released during the first months are subjected to best environmental conditions what is essential for the recruitment of the species due to higher survival. However, depending on the abundance of spawning females smaller than $130 \mathrm{~mm}$, this group can produce a number of larvae as large or larger than the $>130 \mathrm{~mm}$ cohort through sheer size of spawning stock. As such, it is necessary to protect the entire stock of spawning females in the estuary of Patos Lagoon because they support the recruitment of juveniles during the next breeding season.

For a complete understanding of the reproductive cycle of $\mathrm{C}$. sapidus in the Patos Lagoon estuary, it is necessary to clarify some remaining points that are not yet well understood, such as the impact of nearshore current circulation on the ability of larvae hatched near the estuary mouth to recruit within the estuary versus migrating to other regions. Also a study on reproductive, genetic and population parameters along the longitudinal distribution of the species may answer questions about differences between sub-populations within the range of C. sapidus.

\section{ACKNOWLEDGEMENTS}

This study was funded by the National Research Council (CNPq). We are grateful to the trainees of the Laboratory of Decapod Crustaceans at FURG University, especially Paula Falcão, for help with egg counts under the microscope, and Dr. Luiz Felipe Cestari Dumont and Robert P. Dunn for help with the manuscript. The authors are also grateful to the two anonymous reviewers.

\section{REFERENCES}

AGUILAR, R., AH HINES, TG WOLCOTT, DL WOLCOTT, MA KRAMER \& RN LIPCIUS. 2005. The timing and route of movement and migration of post-copulatory female blue crabs, Callinectes sapidus Rathbun, from the upper Chesapeake Bay. Journal of Experimental Marine Biology and Ecology, 319: 117128.

BARUTOT, RA, F D'INCAO, \& DB FONSECA. 2009. Reproductive biology of Neohelice granulata (Decapoda: Varunidae) in two salt marshes of the estuarine region of the Lagoa dos Patos Lagoon, southern Brazil. Journal of the Marine Biology Association of the United Kingdom, 89(4): 769-774.

BEGG, GA \& JR WALDMAN. 1999. An holistic approach to fish stock identification. Fisheries Research, 43:35-44.

BENEDET, RA, D DOLCI \& F D'INCAO. 2010. Descrição técnica e modo de operação das artes de pesca artesanais do camarãorosa no estuário da lagoa dos patos, rio grande do sul, Brasil. Atlântica, 32(1): 5-24. 
BRANCO, JO \& MG AVILAR. 1992. Fecundidade em Callinectes danae Smith (Decapoda, Portunidae) da Lagoa da Conceição, Florianópolis, Santa Catarina, Brasil. Revista Brasileira de Zoologia, 9(3/4): 167-173.

CAPITOLI, RR, CE BEMVENUTI, \& NM GIANUCA. 1978. Estudos de ecologia bentônica na região estuarial da Lagoa dos Patos. I - As comunidades bentônicas. Atlântica, 3: 5-22.

CHURCHILL, EP. JR. 1917-1918. Life history of the blue crab. Bulletin of the Bureau of fisheries, 36: 95-128.

COSTA, TM. 1995. Ciclo reprodutivo de Callinectes danae Smith, 1869 (Crustacea Decapoda, Portunidae) na região de Ubatuba (SP). Universidade Estadual Paulista (Master's Thesis). 94p.

DIAZ, H, JE CONDE \& M BEVILACQUA. 1983. A volumetric method for Estimating Fecundity in Decapoda. Marine Ecology Progress Series, 10: 203-206

DUMONT, LFC \& F D'INCAO. 2004. Growth and reproductive pattern of the caridean shrimp Palaemonetes argentinus Nobili, 1901 (Decapoda-Palaemonidae) in the south of Rio Grande do Sul, Brazil. Nauplius, 12(2): 151-163.

GOVERNO FEDERAL. INMET - Instituto Nacional de Meteorologia. Brasil. Available at www.inmet.gov.br. Accessed on: August, 5th, 2011.

HARTNOLL, RG, 1969. Mating in the Brachyura. Crustaceana, 16(2):161-181

HINES AH. 1988. Fecundity and reproductive output in two species of deep-sea crabs, Geryon fenneri and Geryon quinquedens (Decapoda: Brachyura). Journal of Crustacean Biology. 8(4): 557-562.

JACOBS, JJ, PM BIESIOT, HM PERRY \& C TRIGG. 2003. Biochemical Composition of Embryonic Blue Crabs Callinectes sapidus Rathbun 1896 (Crustacea: Decapoda) from the Gulf of Mexico. Bull. Mar. Sci. 72(2):311-324.

JIVOFF, P, AH HINES \& LS QUACKENBUSH, 2007. Reproduction Biology and Embryonic Development. Chapter 7 In: KENNEDY, VS \& LE CRONIN (eds). The Blue Crab Callinectes sapidus. Maryland Sea Grant.

KENNEDY, VS \& LE CRONIN. 2007. The Blue Crab Callinectes sapidus. Maryland Sea Grant, 774p.

MANTELATTO, FLM \& A FRANSOZO. 1997. Fecundity of the crab Callinectes ornatus Ordway 1863 (Decapoda, Brachyura, Portunidae) from the Ubatuba region, São Paulo, Brazil. Crustaceana, 70(2): 214-226.

MANTELATTO, FLM, JJ O'BRIEN \& R BIAGI. 2003. Parasites and symbionts of crabs from Ubatuba Bay, São Paulo State, Brazil. Comparative Parasitology, 70(2): 211-214.

MEDEIROS, MFST \& LMY OSHIRO. 1990. Aspectos reprodutivos de Callinectes danae Smith 1969 (Crustacea, Decapoda, Portunidae) na Baía de Sepetiba, RJ. An. /l Simp. Ecossis. Costa Sul Sudeste Brasil., ACIESP, 4: 150-159.

MELO, GAS. 1999. Infraordem Brachyura (siris e caranguejos): espécies marinhas e estuarinas. In: Buckup L. \& G. BondBuckup (ed.). Os Crustáceos do Rio Grande do Sul. Editora da UFRGS, Porto Alegre, Brazil, Chap. 25: 415-485.
MENDONÇA, JT, JR VERANI \& N NORDI. 2010. Evaluation and management of the blue crab Callinectes sapidus (Rathbun 1896) (Decapoda - Portunidae) fishery in the Estuary of Cananéia, Iguape and Ilha Comprida, São Paulo, Brazil. Braz. J. Biol., 70(1):37-45.

OLIVEIRA, AR de. 2005. Bioecologia do siri-azul Callinectes sapidus Rathbun 1896, na região estuarina da Lagoa dos Patos, RS, Brasil. Universidade do Rio Grande, Instituto de Oceanografia (Doctoral Thesis). 180p.

PEREIRA, MJP, JO BRANCO, ML CHRISTOFFERSEN, F FREITAS JR., HAA FRACASSO \& TC PINHEIRO. 2009. Population biology of Callinectes danae and Callinectes sapidus (Crustacea: Brachyura: Portunidae) in the southwestern Atlantic. Journal of the Marine Biology Association of the United Kingdom, 89: 1341-1351.

PIOLA, AR, RP MATANO, ED PALMA, OO MÖLLER JR, \& EJD CAMPOS. 2005. The influence of the Plata River discharge on Western South Atlantic shelf. Geophys Res. Lett. 32:1-4.

PRAGER, MH, JR MCCONAUGHA, CM JONES, \& PJ GEER. 1990. Fecundity of blue crab, Callinectes sapidus, in Chesapeake Bay: biological, statistical and management considerations. Bull. Mar. Sci., Univ. Miami, 46 (1): 170-179.

ROBLES, R, CD SCHUBART, JE CONDE, C CARMONA-SUÁREZ, F ALVAREZ, JL VILLALOBOS, \& D FELDER. 2007. Molecular phylogeny of the American Callinectes Stimpson, 1860 (Brachyura: Portunidae), based on two partial mitochondrial genes. Marine Biology, 150:1265-1274.

RODRIGUES, MA \& F D'INCAO. Comparação do crescimento entre Callinectes sapidus (Crustacea, Decapoda, Portunidae) coletados em campo e mantidos em condições controladas. Iheringia, Série Zoologia, 98(3): 372-378.

SÁ, HS. 1987. Relação entre a fecundidade e o tamanho do corpo do siri-tinga Callinectes danae (Crustacea, Portunidae) da Baía de Vitória, Espírito Santo. Revista Cultural, 1: 1-9.

SANTOS, S. 1994. Biologia reprodutiva de Portunus spinimanus Latreille, 1819 (Crustacea, Brachyura, Portunidae) na região de Ubatuba (SP). Universidade Estadual Paulista (Doctoral Thesis). 170p.

SCHEJTER, L \& E SPIVAK. 2005. Morphometry, sexual maturity, fecundity and epibiosis of the South American spider crab Libidoclaea granaria (Brachyura: Majoidea). Journal of the Marine Biology Association of the United Kingdom, 85: 857-863.

SEELIGER U, C ODEBRECHT, JP CASTELLO. Os ecossistemas costeiro e marinho do extremo sul do Brasil. Editora Ecoscientia, Rio Grande Brazil, 337p.

TRUITT, RV. 1939. Our water resources and their conservation. Chesapeake Biological Laboratory Contribution, 27: 10-38.

VORIS, HK. \& WB JEFFRIES. 2001. Distribution and size of a stalked barnacle (Octolasmis muelleri) on the blue crab, Callinectes sapidus. Bulletin of Marine Science, 68(2):181-190.

YAMAMOTO, NU. 1977. Crustáceos decápodes das áreas de pesca de Cananéia, litoral sul do Estado de São Paulo Universidade de São Paulo (Doctoral Thesis). 98p.

Submetido $-22 / 11 / 2010$

Aceito $-07 / 12 / 2011$ 